\title{
Enhancement of the Congo Red Adsorption Capacity of Biochars by Surface Modification with $\mathrm{MgCl}_{2}$ Pretreatment
}

\author{
Hee So $\mathrm{Oh}^{\oplus} \cdot$ Jae-Soo Chang $^{\dagger} \odot$ \\ Department of Environmental Engineering, Korea Maritime and Ocean University
}

(Received September 2, 2020; Revised September 26, 2020; Accepted October 5, 2020)

Objectives: The physicochemical characteristics of Mg-biochar composites derived from kelp and pine after pretreatment with $\mathrm{MgCl}_{2}$ were analyzed, and their adsorption capacities for an anionic dye, Congo red (CR), were evaluated.

Methods: After pretreating $60 \mathrm{~g}$ of kelp and pine sawdust in $1 \mathrm{~L}$ of $0.1 \mathrm{M} \mathrm{MgCl}_{2} \cdot 6 \mathrm{H}_{2} \mathrm{O}$, the raw materials were pyrolyzed at $500^{\circ} \mathrm{C}$ to produce $\mathrm{Mg}$-biochar composites (kelp based $\mathrm{KB}-\mathrm{Mg}$ and pine based $\mathrm{PB}-\mathrm{Mg}$ ). The fundamental physicochemical characteristics of the Mg-biochar composites were examined, and their adsorption capacities for $\mathrm{CR}$ were investigated using different initial $\mathrm{pH}$ values, adsorption kinetic models, and adsorption isotherm models.

Results and discussion: The Mg-biochar composites showed the development of uniform deposits of $\mathrm{Mg}$ minerals primarily as $\mathrm{MgO}$ crystal on the surface by the surface modification with $\mathrm{MgCl}_{2}$. When the pristine biochars were surface-modified with $\mathrm{MgCl}_{2}$, their adsorption capacities for $\mathrm{CR}$ were significantly increased over the entire $\mathrm{pH}$ range tested. The $\mathrm{CR}$ adsorption process by all biochars was best described with the pseudo-first order kinetics model, and the adsorption isotherm characteristics were better described with the Langmuir isotherm model for all biochars. The Langmuir maximum adsorption capacities for KB-Mg and PB-Mg were $423.0 \mathrm{mg} / \mathrm{g}$ and 394.7 $\mathrm{mg} / \mathrm{g}$, respectively. It is suggested that the main mechanism for CR adsorption on the Mg-biochars is electrostatic attraction between $\mathrm{CR}$ and the biochars.

Conclusions: The results showed that surface modification with $\mathrm{MgCl}_{2}$ could greatly enhance the CR adsorption capacity of biochars, and the results demonstrated the great potential of KB-Mg and PB-Mg for CR removal.

Keywords: Biochar, Surface Modification, $\mathrm{MgCl}_{2}$, Congo Red, Adsorption

The Korean text of this paper can be translated into multiple languages on the website of http://jksee.or.kr through Google Translator. 


\section{연구논문}

\section{$\mathrm{MgCl}_{2}$ 전처리를 이용한 표면개질을 통한 바이오차의 Congo red 흡착성능 향상}

오희소 ${ }^{(0)}$ 장재수 ${ }^{+}$

한국해양대학교 환경공학과

목적 : 본 연구에서는 다시마와 소나무를 $\mathrm{MgCl}_{2}$ 로 전처리하여 제조한 $\mathrm{Mg}$-바이오차 복합재(다시마기반 $\mathrm{KB}-\mathrm{Mg}$ 및 소나무 기반 PB-Mg)의 기본적인 물리·화학적 특성을 분석하고 음이온 염료인 Congo red (CR)에 대한 흡착제거 성능을 평가하였다.

방법: 다시마 및 소나무 톱밥 $60 \mathrm{~g}$ 을 $1 \mathrm{~L}$ 의 $0.1 \mathrm{M} \mathrm{MgCl}_{2} \cdot 6 \mathrm{H}_{2} \mathrm{O}$ 용액에서 전처리하고 $500^{\circ} \mathrm{C}$ 에서 열분해하여 $\mathrm{Mg}$ 바이오차를 제조하였다. $\mathrm{Mg}$-바이오차의 기본적인 물리·화학적 특성을 분석하였고, $\mathrm{CR}$ 에 대한 흡착성능을 평가하 기 위해 초기 $\mathrm{pH}$ 에 따른 흡착성능, 흡착 동역학적 특성, 등온 흡착성능 등에 대한 실험을 수행하였다.

결과 및 토의: $\mathrm{MgCl}_{2}$ 로 전처리하여 제조한 $\mathrm{KB}-\mathrm{Mg}$ 와 $\mathrm{PB}-\mathrm{Mg}$ 표면에 $\mathrm{Mg}$ 화합물이 잘 분포되어 있었으며 주로 $\mathrm{MgO}$ 결정체로 존재하였다. $\mathrm{Mg}$-바이오차 복합재는 일반 바이오차와 비교하여 모든 $\mathrm{pH}$ 영역 $(5-10)$ 에서 $\mathrm{CR}$ 에 대 한 흡착 성능이 크게 증가하였다. 모든 바이오차의 $\mathrm{CR}$ 에 대한 흡착 반응이 유사 2 차 반응속도 모델에 가장 적합하 였으며, 모든 바이오차의 등온 흡착성능 특성은 Langmuir 모델이 가장 적합하였고 $\mathrm{KB}-\mathrm{Mg}$ 와 PB-Mg의 CR에 대한 Langmuir 최대 흡착성능은 각각 $423.0 \mathrm{mg} / \mathrm{g}, 394.7 \mathrm{mg} / \mathrm{g}$ 이었다. Mg-바이오차의 $\mathrm{CR}$ 흡착에 대한 주요 기작은 $\mathrm{CR}$ 과 바이오차 간의 정전기 인력으로 판단된다.

결론 : 본 연구는 $\mathrm{MgCl}_{2}$ 를 이용하여 바이오차의 $\mathrm{CR}$ 에 대한 흡착 성능을 크게 향상시킬 수 있음을 보여주었으며, 본 연구에서 제조한 $\mathrm{KB}-\mathrm{Mg}$ 및 $\mathrm{PB}-\mathrm{Mg}$ 의 $\mathrm{CR}$ 흡착제거에 대한 높은 잠재력을 보여주었다.

주제어: 바이오차, 표면개질, 염화마그네슘, 콩고 레드, 흡착

\section{1. 서론}

바이오차는 바이오매스를 열분해한 후 발생하는 고체 부 산물로서 효과적인 탄소 저장 매체로서 여겨지고 있으며 토 양개량제로서 널리 사용되고 있다. ${ }^{1)}$ 바이오차는 또한 하·폐 수로부터 중금속이나 난분해성 유기물질 등을 포함하는 다 양한 오염물질 등의 제거에 흡착제로서 활용할 수 있는 높 은 가능성을 보여주고 있으며 이것과 관련하여 활발한 연구 가 진행되고 있다. ${ }^{2)}$ 특정 오염물질에 대한 바이오차의 흡착 성능을 향상시키기 위하여 공극구조, 비표면적, 표면 작용 기 등 바이오차의 물리·화학적 성질을 개선하기 위한 다양 한 연구들이 수행되어 왔으며, 이러한 바이오차의 성능 개 선은 물리적, 화학적, 생물학적 방법 등의 다양한 기술을 적 용하여 달성할 수 있다. ${ }^{3)}$

여러 가지 바이오차 성능개선 방법 중 열분해하기 전 바이 오매스를 금속 염으로 전처리하여 바이오차의 특정 오염물질
에 대한 흡착 성능을 높일 수 있는 방법에 대한 연구가 활발 히 진행되고 있다. ${ }^{3)}$ 바이오매스를 금속 용액에 담그어서 금 속 이온의 부착을 유도하고 열분해를 시키면 바이오매스에 부착되어 있는 금속 이온이 금속 수산화물 또는 금속 산화물 로 변환이 되어 바이오차 기반 복합재를 제조할 수 있다.4) 바 이오차 표면에 존재하는 이러한 금속 수산화물 또는 금속 산 화물은 바이오차의 표면적을 증가시킬 뿐만 아니라 효과적인 오염물질의 흡착을 위한 반응 면적을 제공한다. ${ }^{4}$ 이런 용도 에 사용되는 금속 염으로는 $\mathrm{AlCl}_{3}{ }^{5}$, $, \mathrm{CaCl}_{2}{ }^{6}, \mathrm{CoCl}_{2}{ }^{7)}, \mathrm{FeCl}_{3}{ }^{8}$, $\mathrm{KMnO}_{4}, \mathrm{MgCl}_{2}{ }^{9}, \mathrm{MnCl}_{2}, \mathrm{Zn}\left(\mathrm{NO}_{3}\right)_{2}$ 와 $\mathrm{ZnCl}_{2}{ }^{10)}$ 등이 보고되었다.

Congo red (CR)는 아조계열 음이온 염료로서 섬유, 인쇄, 염색 산업 등에서 주로 많이 사용되고 있으며 세계에서 가 장 많이 사용되고 있는 염료 중의 하나로 알려져 있다. ${ }^{11,12)}$ $\mathrm{CR}$ 은 복잡한 방향족 구조로 인해 물리적, 화학적 안정성이 높아 잘 분해되지 않고 발암물질에 속하며 많은 생물체에게 독성을 나타낸다. ${ }^{11)}$ 이러한 특성을 가진 $\mathrm{CR}$ 을 바이오차를 
적용하여 흡착 제거하고자 하는 시도들이 이루어져 왔으며, 최근에 $\mathrm{Oh}$ and $\mathrm{Chang}^{13)}$ 은 바이오차의 $\mathrm{CR}$ 에 대한 흡착성능 을 높이기 위해 바이오매스를 $\mathrm{FeCl}_{3}$ 로 처리하여 제조한 자 성 바이오차를 $\mathrm{CR}$ 의 흡착에 적용한 연구를 보고하였다. 다 시마를 $\mathrm{FeCl}_{3}$ 로 전처리하여 제조한 자성 바이오차는 일반 다시마 바이오차와 비교하여 3 배 이상의 $\mathrm{CR}$ 에 대한 흡착성 능을 보여주었지만, 소나무 톱밥을 $\mathrm{FeCl}_{3}$ 로 전처리하여 제 조한 자성 바이오차는 일반 소나무 바이오차와 비교하여 $\mathrm{CR}$ 에 대한 흡착성능이 $20 \%$ 정도 증가하는 데에 그쳐 $\mathrm{CR}$ 에 대한 흡착성능 개선에 한계를 드러내었다.

바이오매스를 $\mathrm{MgCl}_{2}$ 로 전처리한 후 $\mathrm{Mg}$-바이오차 복합재 를 제조하여 인산염, 질산염, 부식산염 등과 같은 오염물질 에 대한 흡착제거 성능을 향상시킨 몇몇 사례들이 보고되었 지만, $\mathrm{Mg}$-바이오차 복합재를 이용한 $\mathrm{CR}$ 에 대한 흡착 제거 에 관한 연구는 아직 보고되고 있지 않다. ${ }^{1,14-17)}$ 본 연구에서 는 $\mathrm{MgCl}_{2}$ 로 전처리한 다시마와 소나무를 열분해하여 $\mathrm{Mg}$ 바이오차 복합재를 제조하고 이 복합재의 CR에 대한 흡착 제거 성능에 대한 특성을 살펴보았다. 바이오차는 일반적 으로 카복실 및 페놀 그룹의 존재로 인해 음전하를 띠고 음 이온 물질의 흡착이 쉽지 않다고 알려져 있다.3) 금속염, $\mathrm{MgCl}_{2}$ 로 바이오매스를 전처리하고 열분해하여 $\mathrm{Mg}$ 를 바이 오차에 부착시켜 표면에서 양전하를 띠게 하면 음전하를 띤 $\mathrm{CR}$ 에 대한 흡착 성능을 증가시킬 수 있을 것이다. ${ }^{1,14}$ 본 연 구에서는 $\mathrm{CR}$ 의 흡착 제거 향상을 위해 $\mathrm{Mg}$-바이오차 복합 재를 제조하여 그 기초적인 물리·화학적 특성을 분석하고 염료 $\mathrm{CR}$ 에 대한 기본적인 흡착 제거 성능을 평가하고 그 작용 기작을 평가하였다.

\section{2. 재료 및 방법}

\section{1. 재료}

실험에서 사용한 $\mathrm{MgCl}_{2} \cdot 6 \mathrm{H}_{2} \mathrm{O}$ 은 Junsei사(19275S0351, Tokyo, Japan)에서 구입하였고 CR은 Sigma-Aldrich사(C6767, Buchs, Switzerland)에서 구입하였다. Mg-바이오차 복합재의 재료로 서 바이오매스는 다시마와 소나무 톱밥을 사용하였으며 다시 마는 부산시에 위치해 있는 수산물 전문 시장에서 구입하였 으며 비교로 사용한 목질 섬유소 물질로 이루어진 소나무 톱밥은 인근 지역 회사에서 제공 받았다.

\subsection{Mg-바이오차 복합재 제조}

바이오매스를 충분히 세척하여 불순물을 제거해서 3 일 동 안 건조 시킨 후 분쇄기로 분쇄하였다. 체를 이용해서 크기 가 $180 \mu \mathrm{m}$ 와 $1.70 \mathrm{~mm}$ 사이에 있는 입자들을 수집하여 실험 에 사용하였다. $\mathrm{Mg}$-바이오차 복합재를 제조하기 위하여 바 이오매스 $30 \mathrm{~g}$ 을 $500 \mathrm{~mL}$ 의 $0.1 \mathrm{M} \mathrm{MgCl}_{2} \cdot 6 \mathrm{H}_{2} \mathrm{O}$ 용액에 넣 어서 2 시간 동안 교반하였다. 80 번 체를 이용하여 용액을
제거하고 건조 오븐(DO-81, (주)한양사이언스)에서 온도를 $80^{\circ} \mathrm{C}$ 로 고정하여 2시간 동안 숙성시킨 후, 표면처리한 바이 오매스를 완전히 건조시켜 열분해를 진행하였다. 표면처리 한 바이오매스 $150 \mathrm{~g}$ 을 열분해기에 넣고 질소가스를 2,500 $\mathrm{cm}^{3} / \mathrm{min}$ 의 유량으로 주입하면서 열분해 온도 $500^{\circ} \mathrm{C}$ 까지 $7{ }^{\circ} \mathrm{C} / \mathrm{min}$ 의 온도 증가율로 온도를 증가시켜 2시간 동안 열 분해하여 $\mathrm{Mg}$-바이오차 복합재를 제조하였다. 대조구로서 $\mathrm{MgCl}_{2} \cdot 6 \mathrm{H}_{2} \mathrm{O}$ 용액으로 처리하지 않은 일반 바이오차도 위 에서 기술한 $\mathrm{Mg}$-바이오차 제조방법과 동일한 방법으로 바 이오매스를 준비하고 동일한 조건으로 열분해하여 제조하 였다. 편의를 위해 다시마 원재료를 Kelp-R이라고 표기하였 고 제조된 바이오차를 $\mathrm{KB}$ 라고 표기하였으며 다시마를 기반 으로 한 $\mathrm{Mg}$-바이오차 복합재는 $\mathrm{KB}-\mathrm{Mg}$ 라고 표기하였다. ${ }^{13)}$ 소나무 톱밥은 Pine-R이라고 표기하였고 소나무 톱밥으로 제조한 바이오차는 $\mathrm{PB}$ 로 표기하였으며 소나무 톱밥을 기반 으로 한 $\mathrm{Mg}$-바이오차 복합재는 $\mathrm{PB}-\mathrm{Mg}$ 로 표기하였다. ${ }^{13)}$

\section{3. 물리·화학적 특성 분석}

각 재료들의 표면에서의 작용기를 파악하기 위해 FTIR (Thermo iS50, Thermo Fisher Scientific, USA)을 이용하여 분석하였다. 바이오차의 표면 형태와 구조를 분석하기 위해 FE-SEM (Field Emission Scanning Electron Microscope: $\mathrm{SUPRA}^{\mathrm{TM}} 25$, Carl Zeiss, Switzerland)을 사용하여 각 재료 들의 표면을 배율을 변화해 가면서 촬영하였고, 바이오차 표면의 원소 구성을 분석하기 위해 EDS (energy-dispersive X-ray spectrometer, APOLLO XPP, AMETEK EDAX, Mahwah, New Jersey, USA)를 사용하여 측정하였다. 각 재료들의 BET 비표면적은 Micrometrics사(USA)에서 제 작된 3Flex \& TriStar 3020 모델을 사용하여 측정하였다. 바이오차에서의 금속 결정을 분석하기 위해 XRD (X-ray diffraction, X'Pert Pro, Philips, Netherland)를 사용하여 $2 \theta$ 각을 $5^{\circ}$ 에서 $80^{\circ}$ 까지 연속적으로 $\mathrm{X}$ 선을 주사하면서 측정하 였다. 바이오차의 등전점 $\left(\mathrm{pH}_{\mathrm{pzc}}\right.$ : point of zero charge)은 Lakshmipathy and $\mathrm{Sarada}^{18)}$ 의 방법을 따라 다음과 같이 측 정하였다. $30 \mathrm{~mL}$ 의 $0.1 \mathrm{M} \mathrm{KCl}$ 용액을 $50 \mathrm{~mL}$ 실험용 유리 병에 넣고 $0.1 \mathrm{M} \mathrm{HCl}$ 또는 $0.1 \mathrm{M} \mathrm{NaOH}$ 용액을 사용하여 초기 $\mathrm{pH}$ 를 조정하였다. 위에서 기술한 대로 여러 개의 유리 병을 준비하고 각 유리병마다 서로 다른 초기 $\mathrm{pH}$ 를 가질 수 있도록 하여 초기 $\mathrm{pH}$ 를 2에서부터 10 까지 조정하였다. 바이오차 $0.1 \mathrm{~g}$ 을 투입하고 48시간 동안 교반한 후, 부유물 을 여과 제거하여 용액의 최종 $\mathrm{pH}$ 를 측정하였다. 초기 $\mathrm{pH}$ 와 최종 $\mathrm{pH}$ 의 차이를 구한 후 이 값의 초기 $\mathrm{pH}$ 값에 대한 그래프를 작성하여 등전점을 구하였다.

\subsection{CR 흡착실험}

용액의 초기 $\mathrm{pH}$ 가 바이오차의 $\mathrm{CR}$ 에 대한 흡착 성능에 미 
치는 영향을 평가하기 위해 $0.1 \mathrm{~g}$ 의 바이오차를 농도 500 $\mathrm{mg} / \mathrm{L}$ 의 $\mathrm{CR}$ 용액 $25 \mathrm{~mL}$ 에 주입하여 흡착 실험을 진행하 였다. $0.1 \mathrm{M} \mathrm{HCl}$ 과 $0.1 \mathrm{M} \mathrm{NaOH}$ 용액을 사용하여 $\mathrm{pH}$ 를 5 - 11 범위에서 조정한 후 시료를 교반하였다. 실내온도(21 $\left.\pm 1^{\circ} \mathrm{C}\right)$ 에서 $200 \mathrm{rpm}$ 으로 48 시간 교반 후 주사기 필터(0.45 $\mu \mathrm{m})$ 를 이용하여 입자를 제거한 후 분광광도계(UV-2450, SHIMADZU, Japan)를 이용하여 파장 $497 \mathrm{~nm}$ 에서 평형농 도를 측정하여 $\mathrm{CR}$ 의 흡착량을 계산하였다.

$\mathrm{CR}$ 의 바이오차에 대한 등온 흡착 실험은 여러 농도의 $\mathrm{CR}$ 용액 $25 \mathrm{~mL}$ 를 주입한 실험용 유리병에 바이오차 $0.1 \mathrm{~g}$ 을 주입하여 $200 \mathrm{rpm}$ 에서 48시간 교반한 후 위에서 기술한 방 법을 따라 평형농도를 측정하고 그 흡착량을 계산하였다. Langmuir 모델과 Freundlich 모델을 사용하여 등온 흡착 해 석을 하였고, Langmuir 및 Freundlich 등온 흡착방정식은 다 음과 같다.

Langmuir 모델: $\mathrm{q}_{\mathrm{e}}=\mathrm{q}_{\mathrm{m}} \mathrm{K}_{\mathrm{L}} \mathrm{C}_{\mathrm{e}} /\left(1+\mathrm{K}_{\mathrm{L}} \mathrm{C}_{\mathrm{e}}\right)$
Freundlich 모델: $\mathrm{q}_{\mathrm{e}}=\mathrm{K}_{\mathrm{F}} \mathrm{C}_{\mathrm{e}}^{1 / \mathrm{n}}$

등온 흡착방정식에서 $\mathrm{q}_{\mathrm{e}}(\mathrm{mg} / \mathrm{g})$ 는 평형상태에서의 흡착제 의 평형 흡착량, $\mathrm{q}_{\mathrm{m}}(\mathrm{mg} / \mathrm{g})$ 은 흡착제의 최대 흡착량, $\mathrm{C}_{\mathrm{e}}$ 는 평형상태에서의 염료의 농도, $\mathrm{K}_{\mathrm{L}}(\mathrm{L} / \mathrm{mg})$ 은 Langmuir 상수 를 나타내며, $\mathrm{K}_{\mathrm{F}}(\mathrm{L} / \mathrm{g})$ 는 Freundlich 상수, $1 / \mathrm{n}$ 은 분리 계수 를 나타낸다. ${ }^{13,19)}$

\section{5. 흡착 반응속도 실험}

$\mathrm{CR}$ 의 바이오차 흡착에 대한 흡착 반응속도 실험을 위해 $\mathrm{CR}$ 용액 $(500 \mathrm{mg} / \mathrm{L}) 25 \mathrm{~mL}$ 와 바이오차 $0.1 \mathrm{~g}$ 를 실험용 유 리병에 주입하고 $21^{\circ} \mathrm{C}$ 에서 $200 \mathrm{rpm}$ 으로 교반하였다. 일정 한 시간 간격을 두고 용액을 채취하여 $0.45 \mu \mathrm{m}$ 시린지 필 터를 이용하여 입자를 제거한 후 흡광도를 측정하였다. 바 이오차에 대한 $\mathrm{CR}$ 흡착의 동역학적 특성을 살펴보기 위 해 아래와 같이 유사 1차 반응속도 모델(PFO: pseudo-first order kinetics model), 유사 2차 반응속도 모델(PSO: pseudo-second order kinetics model), 입자내 확산속도 모델 (IPD: intra-particle diffusion rate model)을 적용하였다.

$$
\begin{aligned}
& \text { PFO: } \mathrm{q}_{\mathrm{t}}=\mathrm{q}_{\mathrm{e}}\left(1-\mathrm{e}^{-\mathrm{k}_{\mathrm{t}} \mathrm{t}}\right) \\
& \text { PSO: } \mathrm{q}_{\mathrm{t}}=\mathrm{q}_{\mathrm{e}}{ }^{2} \mathrm{k}_{2} \mathrm{t} /\left(1+\mathrm{q}_{\mathrm{e}} \mathrm{k}_{2} \mathrm{t}\right) \\
& \text { IPD: } \mathrm{q}_{\mathrm{t}}=\mathrm{k}_{\mathrm{p}} \mathrm{t}^{0.5}+\mathrm{C}
\end{aligned}
$$

위의 식에서 $\mathrm{q}_{\mathrm{t}}(\mathrm{mg} / \mathrm{g})$ 는 정해진 시간에 흡착된 흡착량, $\mathrm{t}$ (h)는 접촉 시간, $\mathrm{q}_{\mathrm{e}}(\mathrm{mg} / \mathrm{g})$ 는 평형상태에서 흡착된 흡착량 을 나타낸다. $\mathrm{k}_{1}(1 / \mathrm{min})$ 은 유사 1 차 반응속도 모델에서의 속도 상수를 나타내며, $\mathrm{k}_{2}(\mathrm{~g} / \mathrm{mg} \cdot \mathrm{min})$ 는 유사 2차 반응속도 모델에서의 속도 상수이다. ${ }^{13)} \mathrm{k}_{\mathrm{p}}$ 는 입자내 확산속도 모델의 상수이고 $\mathrm{C}$ 값은 경계층 효과를 나타내는 상수이다. $\mathrm{C}$ 값이
커질수록 경계층 효과가 크다는 것을 나타낸다. ${ }^{19)}$

\section{3. 결과 및 고찰}

\section{1. 바이오차 특성}

FTIR을 이용하여 분석한 바이오차 원재료, 일반 바이오차 및 $\mathrm{Mg}$-바이오차 복합재의 표면 작용기 구성을 Fig. 1에 나 타내었다. 바이오차 표면에서의 작용기는 오염물질에 대한 그 흡착 특성을 결정하는 중요한 인자이며 주로 바이오차 원재료와 열분해 온도에 의해 결정된다고 알려져 있다. ${ }^{20)}$ 다시마 기반 일반 바이오차 및 $\mathrm{Mg}$-바이오차와 원재료의 FTIR 스펙트럼(Fig. 1(a))은 서로 약간의 차이가 있기는 하 지만 모두 비슷한 형태의 피크를 보여주었다. FTIR 스펙트 럼 분석결과 모든 시료에서 $\mathrm{O}-\mathrm{H}$ stretching $\left(3,451 \mathrm{~cm}^{-1}\right), \mathrm{C}$ $=\mathrm{C}$ stretching $\left(1,631 \mathrm{~cm}^{-1}\right), \mathrm{C}-\mathrm{C}$ stretching $\left(1,401 \mathrm{~cm}^{-1}\right)$ 이 관찰되었고, 원재료인 Kelp-R에서는 나타나지 않은 $\mathrm{C}-\mathrm{O}$ stretching $\left(1,114 \mathrm{~cm}^{-1}\right)$ 이 $\mathrm{KB}$ 와 $\mathrm{KB}-\mathrm{Mg}$ 에는 관찰되었다. ${ }^{21)}$ 방향성 또는 비닐 $\mathrm{C}-\mathrm{H}$ stretching $\left(867 \mathrm{~cm}^{-1}, 613 \mathrm{~cm}^{-1}\right)$ 에 해당하는 피크들도 원재료인 Kelp-R에서는 나타나지 않고
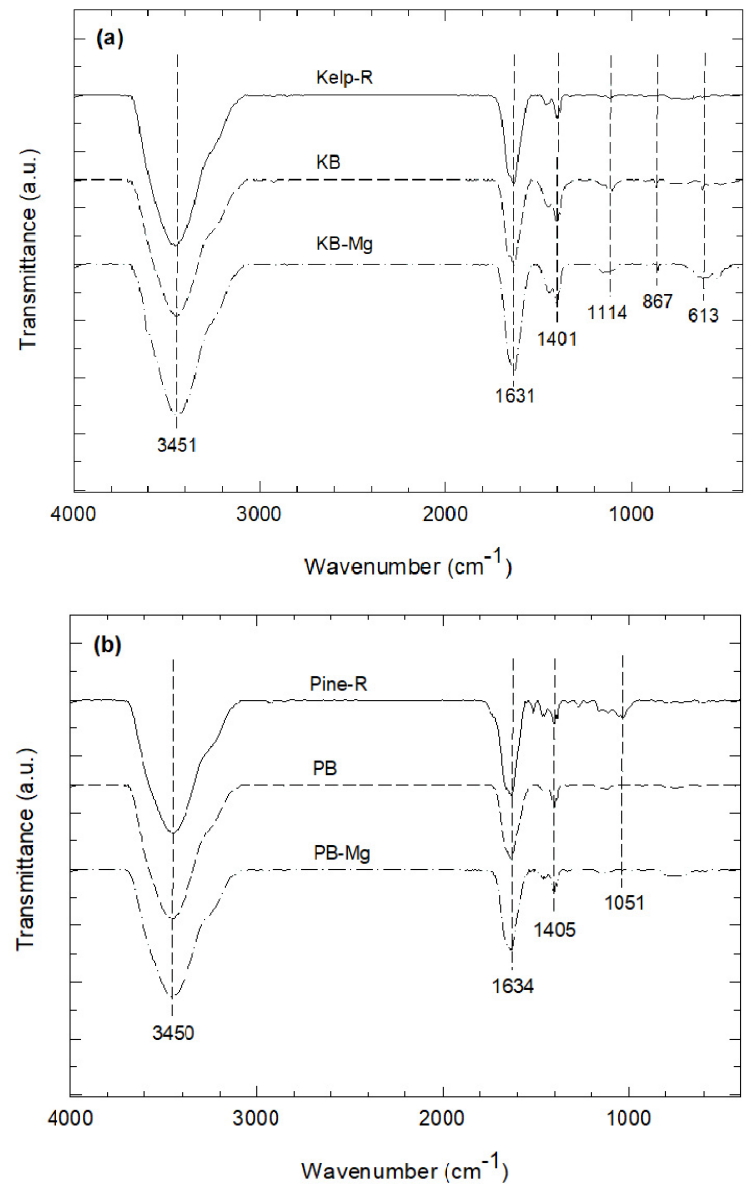

Fig. 1. FTIR spectra of (a) kelp, kelp-based biochar and Mg-biochar composite, and (b) pine, pine-based biochar and Mg-biochar composite. 


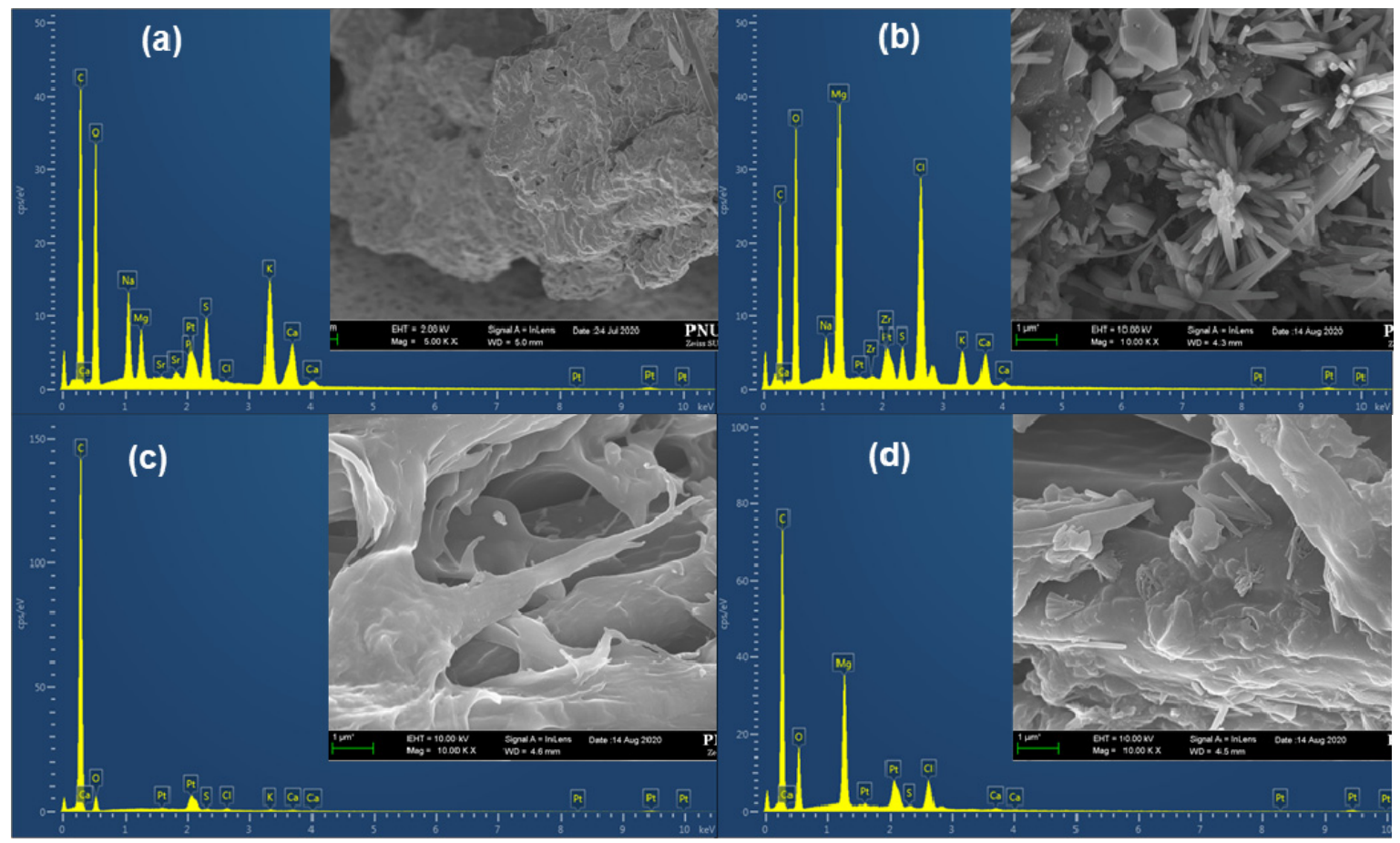

Fig. 2. SEM image and EDS spectrum pattern for each biochar sample. (a) KB, (b) KB-Mg, (c) PB, (d) PB-Mg. Magnification = 5,000 for (a), 10,000 for (b), (c), and (d).

$\mathrm{KB}$ 와 $\mathrm{KB}-\mathrm{Mg}$ 에서만 관찰되었다. ${ }^{1}$ 다시마 바이오차의 FTIR 스펙트럼 결과는 기존의 연구결과 ${ }^{21}$ 와 유사한 형태를 나타 내었으며, 다시마를 열분해하였을 경우 작용기의 종류가 원 재료에 비해 조금 증가하였다. 소나무를 열분해하였을 경우 FTIR 스펙트럼의 피크 수가 감소하였으며 열분해하여 제조 한 PB와 PB-Mg는 비슷한 형태의 스펙트럼을 나타내었다 (Fig. 1(b)). FTIR 스펙트럼 분석결과 모든 시료에서 $\mathrm{O}-\mathrm{H}$ stretching $\left(3,450 \mathrm{~cm}^{-1}\right), \mathrm{C}=\mathrm{C}$ stretching $\left(1,634 \mathrm{~cm}^{-1}\right), \mathrm{C}-\mathrm{C}$ stretching $\left(1,405 \mathrm{~cm}^{-1}\right)$ 이 관찰되었으며 $\mathrm{C}-\mathrm{O}$ stretching $\left(1,051 \mathrm{~cm}^{-1}\right)$ 은 단지 원재료인 Pine-R에서만 관찰되었다. 소 나무 바이오차의 FTIR 스펙트럼 결과도 기존의 연구결과 ${ }^{21)}$ 와 유사한 형태를 나타내었으며, 소나무는 열분해하였을 경 우 작용기의 종류가 원재료에 비해 조금 감소하는 것을 확 인할 수 있다. 위에서 살펴본 것처럼, 작용기를 더 많이 함 유하고 있는 다시마 기반 바이오차인 KB와 KB-Mg가 소나 무기반 바이오차인 $\mathrm{PB}$ 나 $\mathrm{PB}-\mathrm{Mg}$ 보다도 $\mathrm{CR}$ 흡착에 더 효과 적일 것으로 판단된다. ${ }^{22)}$

Fig. 2는 일반 바이오차 및 Mg-바이오차 복합재의 SEM 이미지 및 $\mathrm{EDS}$ 분석결과를 나타낸 것이다. Fig. 2(a), Fig. 2(b), Fig. 2(c) 그리고 Fig. 2(d)는 각각 $\mathrm{KB}, \mathrm{KB}-\mathrm{Mg}, \mathrm{PB}$ 그 리고 $\mathrm{PB}-\mathrm{Mg}$ 를 나타낸다. SEM 이미지는 일반 바이오차 $(\mathrm{KB}, \mathrm{PB})$ 가 $\mathrm{Mg}$-바이오차 $(\mathrm{KB}-\mathrm{Mg}, \mathrm{PB}-\mathrm{Mg})$ 에 비해 표면의 거칠기가 작으며 일반 바이오차의 표면에서는 발견되지 않 던 입자들이 $\mathrm{Mg}$-바이오차의 표면에서는 발견된다는 것을 보여준다. 이러한 입자들은 $\mathrm{EDS}$ 분석과 XRD 분석을 통해
Table 1. EDS elemental content of the pristine biochars and Mg-biochars.

\begin{tabular}{ccccc} 
Element & KB & KB-Mg & PB & PB-Mg \\
C & 18.89 & 11.56 & 66.76 & 29.36 \\
$\mathrm{O}$ & 24.47 & 25.85 & 3.98 & 11.90 \\
$\mathrm{Mg}$ & 2.08 & 11.75 & $\mathrm{nd}$ & 10.68 \\
$\mathrm{Na}$ & 5.32 & 2.44 & $\mathrm{nd}$ & $\mathrm{nd}$ \\
$\mathrm{S}$ & 3.64 & 1.96 & 0.1 & 0.15 \\
$\mathrm{Cl}$ & 0.14 & 13.47 & 0.31 & 3.41 \\
$\mathrm{~K}$ & 10.20 & 3.26 & 0.24 & $\mathrm{nd}$ \\
$\mathrm{Ca}$ & 4.42 & 3.37 & 0.27 & 0.28 \\
\hline
\end{tabular}

Values are weight \%. nd: not detected.

마그네슘 화합물이라는 것을 확인할 수 있다. 다시마 기반 일반 바이오차인 $\mathrm{KB}$ 의 $\mathrm{EDS}$ 스펙트럼에서 여러 가지 원소 들이 감지가 되었는데 $\mathrm{KB}$ 는 $\mathrm{C}, \mathrm{O}, \mathrm{Na}, \mathrm{K}, \mathrm{Ca}, \mathrm{S}$ 등의 원소 들 뿐만 아니라 $\mathrm{Mg}$ 도 함유하고 있음을 알 수 있다(Table 1). 이 $\mathrm{KB}$ 를 $\mathrm{MgCl}_{2}$ 로 표면개질한 $\mathrm{KB}-\mathrm{Mg}$ 는 원소구성에는 변 화가 없었지만 $\mathrm{Mg}$ 가 그 무게비율이 $2.08 \%$ 에서 $11.75 \%$ 로 크게 증가하는 것을 Table 1은 보여준다. 소나무 기반 일반 바이오차인 $\mathrm{PB}$ 의 경우 구성 원소의 종류도 $\mathrm{KB}$ 에 비해 제 한적이었고 $\mathrm{Mg}$ 를 함유하고 있지도 않았으나 이 $\mathrm{PB}$ 를 표면 개질한 PB-Mg는 $10.68 \%$ 의 Mg를 함유하고 있었다(Table 1). 이러한 결과는 $\mathrm{KB}-\mathrm{Mg}$ 와 $\mathrm{PB}-\mathrm{Mg}$ 모두 표면개질을 통해 $\mathrm{Mg}$ 화합물이 바이오차 표면에 잘 분포되어 있다는 것을 보여준 


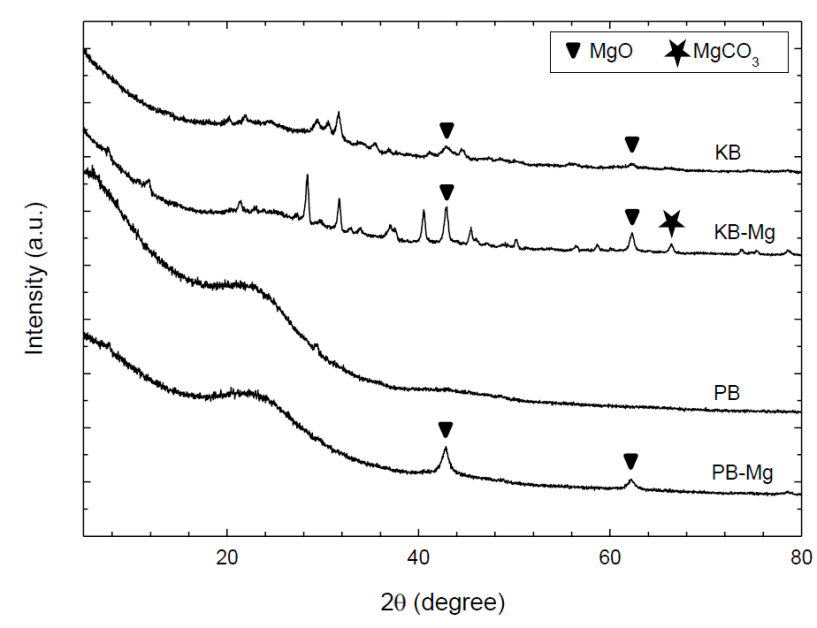

Fig. 3. XRD patterns of pristine biochar and Mg-biochar samples.

다.

$\mathrm{Li}$ et al. ${ }^{15)}$ 은 수탕수수 폐기물을 기반으로 $\mathrm{MgCl}_{2}$ 로 표면 개질하여 제조한 $\mathrm{Mg}$-바이오차에서 $\mathrm{MgO}$ 결정체가 표면 전 체에 균일하게 부착되어 있다고 보고 하였다. Shin et al. ${ }^{1)}$ 또한 커피박을 기반으로 $\mathrm{MgCl}_{2}$ 로 표면개질하여 제조한 $\mathrm{Mg}$-바이오차 표면에서 주요 결정체가 $\mathrm{MgO}$ 임을 발표하였 다. Novais et al. ${ }^{16}$ 은 가금류 분뇨와 사탕수숫대를 $\mathrm{MgCl}_{2}$ 로 표면개질하여 제조한 $\mathrm{Mg}$-바이오차 표면에 $\mathrm{Mg}$ 결정체가 $\mathrm{MgO}$ 뿐만이 아니라 $\mathrm{MgSiO}$ 도 형성되어 있다는 것을 보고하 였다. Fig.3은 본 연구에서 제조한 일반 바이오차 및 $\mathrm{Mg}$-바 이오차의 XRD 분석 회절도를 나타낸 것이다. XRD 회절도 에서 $2 \theta$ 가 $42.8,62.2$ 도에서의 회절 피크는 $\mathrm{MgO}$ 결정 구조 를 가리킨다. XRD 회절도는 다시마 바이오차인 $\mathrm{KB}$ 에 $\mathrm{Mg}$ 결정체가 $\mathrm{MgO}$ 형태로 존재한다는 것을 보여주며 이 결정체 의 $\mathrm{Mg}$ 는 원재료인 다시마가 원래 함유하고 있던 것에서 기 인한 것이다. ${ }^{23)} \mathrm{Mg}$ 결정체로서 $\mathrm{MgO}$ 가 KB-Mg와 $\mathrm{PB}-\mathrm{Mg}$ 에 서 모두 관찰되었는데, 이것은 열분해 공정 중 바이오매스 가 탄화되는 동안 부착되어 있는 $\mathrm{MgCl}_{2}$ 가 탈수화 반응을 통해 $\mathrm{MgO}$ 를 형성한 것으로 사료된다. ${ }^{1)}$ 수용액에서 $\mathrm{MgO}$ 는 다음 반응식과 같이 반응하여 표면에 양전하를 띠게 되고 음전하 물질에 대해 인력이 발생한다고 알려져 있다. ${ }^{1,15}$

$$
\equiv \mathrm{MgO}+\mathrm{H}_{2} \mathrm{O} \rightarrow \equiv \mathrm{MgOH}^{+}+\mathrm{OH}^{-}
$$

위에서 기술한 $\mathrm{EDS}$ 와 $\mathrm{XRD}$ 분석결과는 본 연구에서 사 용한 방법을 통해 바이오차에 성공적으로 $\mathrm{Mg}$ 를 부착하여 $\mathrm{Mg}$-바이오차 복합재를 제조할 수 있다는 것을 보여준다.

\section{2. $\mathrm{CR}$ 흡착에 대한 $\mathrm{pH}$ 의 영향}

폐수로부터 염료를 흡착 제거할 경우에 일반적으로 $\mathrm{pH}$ 가 그 제거율에 가장 큰 영향을 미치는 인자의 하나로 알려져 있다. ${ }^{24)}$ Fig.4는 초기 $\mathrm{CR}$ 용액의 $\mathrm{pH}$ 가 바이오차 및 $\mathrm{Mg}$-바

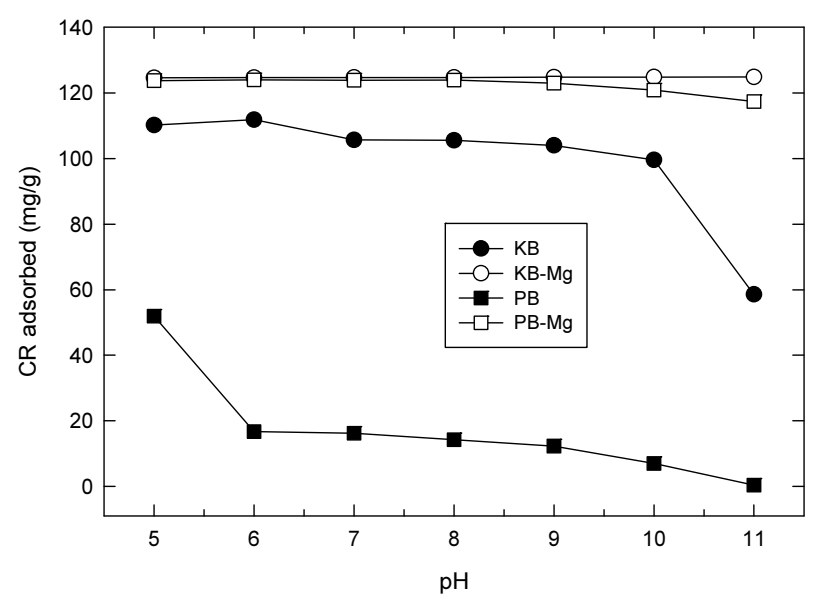

Fig. 4. Amount of $C R$ adsorbed on the biochars at different initial $\mathrm{pH}$ values $\left(\mathrm{C}_{0}=500 \mathrm{mg} / \mathrm{L}\right.$; temperature $=21 \pm$ $1^{\circ} \mathrm{C}$; shaking speed $=200 \mathrm{rpm}$; contact time $=48 \mathrm{~h}$ ). ${ }^{13)}$

이오차 복합재의 $\mathrm{CR}$ 에 대한 흡착에 미치는 영향을 나타낸 것이다. 다시마 기반 바이오차인 $\mathrm{KB}$ 는 $\mathrm{CR}$ 에 대한 흡착량 이 $\mathrm{pH}$ 6까지는 $110 \mathrm{mg} / \mathrm{g}$ 정도에서 일정한 수준으로 유지되 다가 $\mathrm{pH}$ 가 증가하면서 그 흡착량이 조금씩 감소하고 $\mathrm{pH} 10$ 부터는 $\mathrm{CR}$ 에 대한 흡착량이 급격하게 감소하는 추세를 나 타내었다. 소나무 기반 바이오차인 $\mathrm{PB}$ 는 $\mathrm{CR}$ 에 대한 흡착량 이 $\mathrm{pH} 5$ 에서 $52 \mathrm{mg} / \mathrm{g}$ 으로서 최고치를 나타내었으며 $\mathrm{pH} 6$ 에서 급격하게 감소한 후, $\mathrm{pH}$ 가 증가할수록 흡착량이 조금 씩 감소하는 추세를 나타내었다. Fig. 4는 $\mathrm{KB}, \mathrm{PB}$ 모두 $\mathrm{MgCl}_{2}$ 로 표면개질을 하면 $\mathrm{CR}$ 에 대한 흡착성능을 크게 증 가시킬 수 있다는 것을 보여주는데, $\mathrm{KB}-\mathrm{Mg}$ 는 실험에서 사 용한 전 $\mathrm{pH}$ 영역에서 $\mathrm{CR}$ 에 대한 최고의 흡착량 $(124.7 \mathrm{mg} / \mathrm{g})$ 을 나타내었으며 $\mathrm{PB}-\mathrm{Mg}$ 는 $\mathrm{PB}$ 와 비교하여 $\mathrm{CR}$ 에 대한 흡착 성능이 실험에서 사용한 전 $\mathrm{pH}$ 영역에서 작게는 2.4 배에서 크게는 292 배까지 극적으로 증가하였다. 수용액에서 $\mathrm{CR}$ 은 대부분의 $\mathrm{pH}$ 영역 $(\mathrm{pH}>5)$ 에서 음전하를 띠는 것으로 알려 져 있다. ${ }^{24)}$ 실험에서 사용한 4 가지 바이오차, $\mathrm{KB}, \mathrm{KB}-\mathrm{Mg}$, $\mathrm{PB}, \mathrm{PB}-\mathrm{Mg}$ 의 등전점은 각각 $10.63,11.1,6.67,10.71$ 이었다 (Table 2). $\mathrm{CR}$ 용액의 $\mathrm{pH}$ 가 흡착제의 등전점보다도 작은 범 위에서는 양전하를 띠는 흡착제의 표면과 음이온 $\mathrm{CR}$ 사이 에 높은 정전기 인력이 작용한다. ${ }^{24)} \mathrm{pH}$ 가 증가할수록 흡착 제 표면에서 양이온으로 하전된 사이트 수는 감소하고 음이 온으로 하전된 사이트 수는 증가한다고 알려져 있다. ${ }^{24)}$ 이 러한 흡착제 표면에서의 전하 특성이 Fig. 4에서 나타내는 것처럼 $\mathrm{pH}$ 변화에 따른 $\mathrm{CR}$ 흡착량 변화의 결과를 가져 왔 다고 판단된다. ${ }^{24)}$ 특별히 $\mathrm{PB}$ 의 경우 등전점은 6.67 로서 4 가 지 흡착제 중에서 가장 낮은 값을 나타내었는데 $\mathrm{CR}$ 에 대한 흡착성능도 모든 $\mathrm{pH}$ 영역에서 가장 낮은 수준을 나타내었 다. 이 $\mathrm{PB}$ 를 $\mathrm{MgCl}_{2}$ 로 표면개질하면 등전점도 급격하게 증 가하였으며 거의 모든 $\mathrm{pH}$ 영역에서 $\mathrm{KB}-\mathrm{Mg}$ 와 비슷한 수준 의 $\mathrm{CR}$ 흡착성능을 나타내었다. 
Table 2. Physical and chemical properties of the pristine biochars and Mg-biochars. ${ }^{13)}$

\begin{tabular}{cccccc} 
& Yield $(\%)$ & Ash $(\%)$ & pH & pH $H_{\text {pzc }}$ & Surface area $\left(\mathrm{m}^{2} / \mathrm{g}\right)$ \\
Kelp-R & - & 11.7 & 6.83 & 5.64 & 0.167 \\
KB & 33.2 & 35.6 & 10.28 & 10.63 & 0.432 \\
KB-Mg & 38.7 & 36.2 & 10.60 & 11.12 & 2.801 \\
Pine-R & - & 0.34 & 4.59 & 3.38 & 0.308 \\
PB & 26.5 & 11.2 & 6.84 & 6.67 & 231.4 \\
PB-Mg & 37.4 & 14.3 & 9.98 & 10.71 & 186.8 \\
\hline
\end{tabular}

Table 3. Parameter estimates and coefficients of determination of kinetic models for CR adsorption on the biochars. ${ }^{13)}$

\begin{tabular}{|c|c|c|c|c|c|}
\hline \multicolumn{2}{|c|}{ Kinetic model } & KB & KB-Mg & PB & PB-Mg \\
\hline \multirow{3}{*}{ PFO } & $\mathrm{q}_{\mathrm{e}}$ & 32.29 & 112.3 & 25.06 & 103.2 \\
\hline & $\mathrm{k}_{1}$ & 0.855 & 0.533 & 0.427 & 0.494 \\
\hline & $\mathrm{R}^{2}$ & 0.8564 & 0.9436 & 0.8638 & 0.9414 \\
\hline \multirow{3}{*}{ PSO } & $\mathrm{q}_{\mathrm{e}}$ & 35.85 & 126.15 & 29.18 & 117.23 \\
\hline & $k_{2}$ & 0.030 & 0.006 & 0.016 & 0.005 \\
\hline & $\mathrm{R}^{2}$ & 0.9064 & 0.9461 & 0.9208 & 0.9597 \\
\hline \multirow{3}{*}{$\mathrm{IPD}$} & $\mathrm{k}_{\mathrm{i}}$ & 4.94 & 19.62 & 5.11 & 19.00 \\
\hline & $C$ & 14.91 & 37.52 & 5.79 & 30.07 \\
\hline & $\mathrm{R}^{2}$ & 0.7509 & 0.7329 & 0.8164 & 0.6906 \\
\hline
\end{tabular}

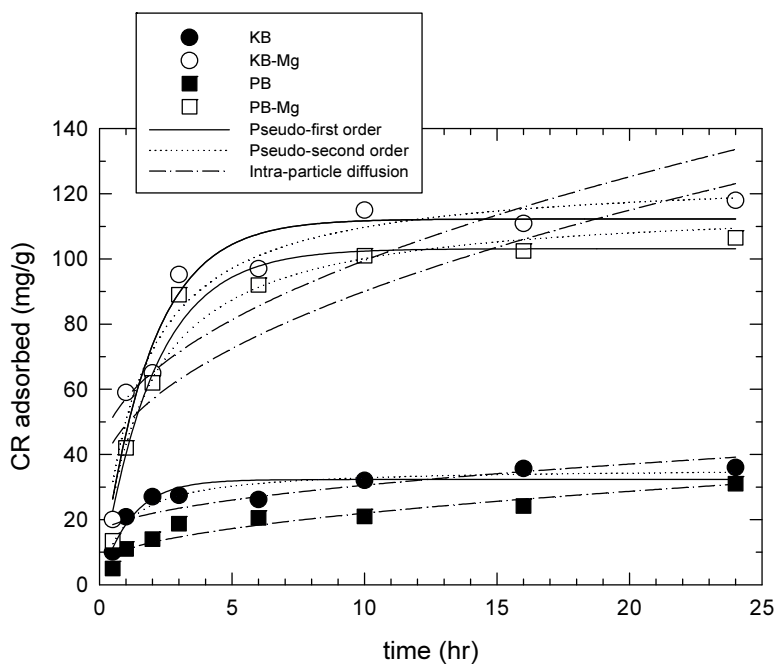

Fig. 5. CR adsorbed on the biochars according to contact time $\left(C_{0}=500 \mathrm{mg} / \mathrm{L}\right.$; temperature $=21 \pm 1^{\circ} \mathrm{C}$; shaking speed $=200 \mathrm{rpm}$; contact time $=48 \mathrm{~h}){ }^{13)}$

\section{3. 흡착동력학적 특성}

일반 바이오차 및 $\mathrm{Mg}$-바이오차의 시간에 따른 $\mathrm{CR}$ 흡착 량을 Fig. 5에 나타내었다. 바이오차 종류에 따른 $\mathrm{CR}$ 의 흡 착 동력학적 경향을 유사 1 차 반응속도 모델, 유사 2 차 반 응속도 모델, 그리고 입자내 확산속도 모델을 이용하여 분 석하였고, 그래프 피팅을 통해 얻은 반응속도 모델의 파라 미터 값들 및 결정계수를 Table3에 나타내었다. 일반 바이 오차 $\mathrm{KB}, \mathrm{PB}$ 에 대한 $\mathrm{CR}$ 의 흡착은 초기 2 시간 정도까지는
흡착이 빠르게 증가하였지만 그 이후에는 흡착이 느리게 진 행되어 16 시간 정도 지났을 때 평형에 도달하였다. 두 바이 오차에 대한 평형 흡착량은 $\mathrm{PFO}$ 모델에 따르면 각각 32.3 $\mathrm{mg} / \mathrm{g}, 25.2 \mathrm{mg} / \mathrm{g}$ 으로 추정되었다. $\mathrm{Mg}$-바이오차인 $\mathrm{KB}-\mathrm{Mg}$, $\mathrm{PB}-\mathrm{Mg}$ 에 대한 $\mathrm{CR}$ 의 흡착은 초기 3 시간 정도까지는 급격하 게 증가하였고 그 이후에는 흡착이 느리게 진행되어 16시간 정도 지났을 때 평형에 도달하였다. 두 바이오차에 대한 평 형 흡착량 추정치는 $\mathrm{PFO}$ 모델에 따르면 각각 $112.3 \mathrm{mg} / \mathrm{g}$, $103.2 \mathrm{mg} / \mathrm{g}$ 으로서 $\mathrm{KB}, \mathrm{PB}$ 와 비교하여 각각 3.5 배, 4 배 정도 증가하였다. 흡착 동력학 실험에서 $\mathrm{KB}-\mathrm{Mg}, \mathrm{PB}-\mathrm{Mg}$ 의 경우, $\mathrm{CR}$ 에 대한 초기의 빠른 흡착 속도는 양전하로 하전된 $\mathrm{Mg}-$ 바이오차의 표면과 음전하로 하전된 $\mathrm{CR}$ 이온과의 정전기적 인력으로부터 기인한 것이라고 판단된다. ${ }^{15)}$ 초기에 빠른 흡 착 반응속도를 보이다가 반응속도가 느려지는 현상은 다른 연구에서 발표된 결과들과 비슷한 결과로서 흡착 시간이 경 과하면서 흡착 표면의 활성 부위가 점점 포화되면서 흡착이 느리게 진행되기 때문인 것으로 알려져 있다. ${ }^{25,26)}$ Table 3에 나타낸 흡착 반응속도 모델의 결정계수 $\left(\mathrm{R}^{2}\right)$ 는 모든 바이오 차에서 $\mathrm{CR}$ 에 대한 흡착이 유사 1 차 반응속도 모델 $\left(\mathrm{R}^{2}=\right.$ $0.8564 \sim 0.9436)$ 보다 유사 2 차 반응속도 모델 $\left(\mathrm{R}^{2}=0.9064\right.$ 0.9597)을 더 잘 따른다는 것을 나타낸다. 이러한 결과는 바이오차에 의한 $\mathrm{CR}$ 의 흡착 기작이 전자의 공유나 교환을 포함하는 화학적 흡착을 주로 따른다는 것을 나타낸다. ${ }^{25,27)}$ 일반적으로 흡착은 용액에서의 흡착질의 이동, 흡착제 외부 표면에서의 확산 이동, 공극 이동, 흡착 등의 4 단계를 거쳐 
진행된다고 알려져 있으며 이 중에서 두 번째와 세 번째 단 계가 흡착 반응속도를 결정짓는 단계로 알려져 있다. ${ }^{19,28)}$ 입 자내 확산속도 모델은 흡착제 내에서의 오염물질의 흡착 공 정을 기술하는 것으로서 실험에서 사용한 모든 바이오차의 입자내 확산속도 모델 상수, $\mathrm{C}$ 값이 0 보다 큰 값을 나타내었 다. ${ }^{26)}$ 이러한 결과는 경계층을 통과하는 $\mathrm{CR}$ 의 질량 이전이 반응속도를 결정하는 요소임을 보여주는 것이다. ${ }^{19)} \mathrm{CR}$ 의 흡착에 대한 모든 바이오차의 입자내 확산속도 모델의 결정 계수는 낮은 값 $\left(\mathrm{R}^{2}=0.6906-0.8164\right)$ 을 보여주었는데, 이 러한 결과는 공극 확산이 반응속도를 결정하는 단계가 아니 라는 것을 나타낸다. ${ }^{19}$

\section{4. 등온 흡착}

바이오차의 CR에 대한 등온흡착 그래프의 Langmuir, Freundlich 모델링 결과를 Table 4에 나타내었다. Langmuir 모델을 이용하여 $\mathrm{CR}$ 에 대한 $\mathrm{KB}, \mathrm{KB}-\mathrm{Mg}, \mathrm{PB}, \mathrm{PB}-\mathrm{Mg}$ 의 최 대 흡착량을 추정한 값은 $145.6,423.0,25.4,394.7 \mathrm{mg} / \mathrm{g}$ 으 로 나타났다. $\mathrm{CR}$ 에 대한 최대 흡착량이 $145.6 \mathrm{mg} / \mathrm{g}$ 인 KB를 $\mathrm{MgCl}_{2}$ 로 표면개질하였을 경우 그 흡착량이 3 배 가까이 증 가하였고, $\mathrm{PB}$ 의 경우 $\mathrm{CR}$ 에 대한 최대 흡착량이 $25.4 \mathrm{mg} / \mathrm{g}$ 수준에서 $\mathrm{MgCl}_{2}$ 표면개질을 통해 그 흡착량을 15 배 이상 증가시켰다. $\mathrm{KB}$ 와 $\mathrm{PB}$ 가 $\mathrm{CR}$ 의 흡착성능에 대해 차이를 나 타내는 것은 두 바이오차의 등전점의 차이, 표면 작용기의 차이, 그리고 바이오차와 염료의 정전기적 상호작용의 차이 등에 따른 것으로 판단된다. ${ }^{13,29)}$ 연구에서 사용한 모든 바이 오차의 $\mathrm{CR}$ 에 대한 흡착성능 평가 실험에서 얻어진 데이터 가 Freundlich 모델 $\left(\mathrm{R}^{2}=0.8465\right.$ - 0.9667)보다도 Langmuir 모델 $\left(\mathrm{R}^{2}=0.9356-0.9724\right)$ 에 더 적합하다는 결과가 나왔 다. 이러한 결과는 $\mathrm{KB}$ 와 $\mathrm{PB}$ 뿐만이 아니라 $\mathrm{Mg}$-바이오차 복
합재에서도 $\mathrm{CR}$ 의 흡착이 주로 단일층에 의해 이루어지며 $\mathrm{CR}$ 이 바이오차 표면에 포화상태에 도달하는 동안 균일하게 분포되어진다는 것을 의미한다. ${ }^{30,31)}$ Table 2가 보여주는 것 처럼 $\mathrm{BET}$ 비표면적은 $\mathrm{KB}\left(0.432 \mathrm{~m}^{2} / \mathrm{g}\right), \mathrm{KB}-\mathrm{Mg}\left(2.801 \mathrm{~m}^{2} / \mathrm{g}\right)$ 보다도 $\mathrm{PB}\left(231.4 \mathrm{~m}^{2} / \mathrm{g}\right), \mathrm{PB}-\mathrm{Mg}\left(186.8 \mathrm{~m}^{2} / \mathrm{g}\right)$ 가 훨씬 큰 값 을 나타내었지만, 이러한 특성이 $\mathrm{PB}, \mathrm{PB}-\mathrm{Mg}$ 의 $\mathrm{CR}$ 에 대한 흡착성능의 증가로는 연결되지 않았다. 이러한 결과는 바이 오차의 $\mathrm{CR}$ 에 대한 흡착 기작으로서의 공극 채움은 무시할 수 있으며, $\mathrm{CR}$ 흡착 기작으로서 $\pi-\pi$ 상호작용이나 정전기 인력이 작용했을 것으로 사료된다. ${ }^{32)} \mathrm{Wu}$ et al. ${ }^{26)}$ 은 리치 표 피 바이오차를 이용한 양이온 음이온 염료에 대한 흡착 연 구에서 염료의 흡착은 주로 염료 분자와 바이오차 표면의 정전기 상호작용에 의해 결정된다고 보고하였다. Sewu et al. ${ }^{19)}$ 과 Nautiyal et al. ${ }^{33)}$ 도 바이오차를 이용한 염료의 흡착 에 중요한 결정 인자로서 염료 분자와 바이오차 표면의 하 전 특성이라는 것을 보고 하였다. 본 연구에서 Fig.4가 보 여주는 것처럼 $\mathrm{pH}$ 에 따른 바이오차의 $\mathrm{CR}$ 에 대한 흡착 성능 의 변화는 바이오차의 $\mathrm{CR}$ 에 대한 흡착의 주요 기작이 $\mathrm{CR}$ 과 바이오차간의 정전기 인력이라는 것을 나타낸다.

$\mathrm{KB}-\mathrm{Mg}$ 와 $\mathrm{PB}-\mathrm{Mg}$ 의 $\mathrm{CR}$ 에 대한 Langmuir 최대 흡착성능 은 각각 $423.0 \mathrm{mg} / \mathrm{g}, 394.7 \mathrm{mg} / \mathrm{g}$ 이고 Table 5는 최근에 발표 된 여러 가지 바이오차의 $\mathrm{CR}$ 에 대한 최대 흡착성능을 정리 하여 놓은 것이다. 본 연구에서 제조한 두 $\mathrm{Mg}$-바이오차의 최대 흡착성능은 Dai et al. ${ }^{32)}$ 이 보고한 게 껍질로 제조한 바 이오차 $(20,317 \mathrm{mg} / \mathrm{g})$ 보다는 낮았지만, Chen et al. ${ }^{34)}$ 의 녹조 류 바이오차(345.2 mg/g), Sewu et al. ${ }^{19)}$ 의 볏짚 바이오차 $(190.8 \mathrm{mg} / \mathrm{g})$, Yek et al. ${ }^{35)}$ 의 증기로 표면개질한 오렌지 표 피 바이오차 $(192.3 \mathrm{mg} / \mathrm{g})$, Park et $\mathrm{al}^{36)}$ 의 지팽이 바이오차 $(22.6 \mathrm{mg} / \mathrm{g})$ 보다 더 높게 나타났다. 이러한 결과는 $\mathrm{MgCl}_{2}$ 를

Table 4. Parameters of isotherm models for CR adsorption on the biochars. ${ }^{13)}$

\begin{tabular}{|c|c|c|c|c|c|c|}
\hline \multirow{2}{*}{ Adsorbent } & \multicolumn{3}{|c|}{ Langmuir isotherm } & \multicolumn{3}{|c|}{ Freundlich isotherm } \\
\hline & $q_{m}(\mathrm{mg} / \mathrm{g})$ & $\mathrm{K}_{\mathrm{L}}(\mathrm{L} / \mathrm{mg})$ & $R^{2}$ & $\mathrm{~K}_{\mathrm{F}}(\mathrm{L} / \mathrm{g})$ & $1 / n$ & $R^{2}$ \\
\hline KB & 145.61 & 0.0150 & 0.9504 & 20.65 & 0.2906 & 0.9497 \\
\hline KB-Mg & 422.98 & 0.0342 & 0.9451 & 91.07 & 0.2445 & 0.9378 \\
\hline PB & 25.39 & 0.3005 & 0.9356 & 11.88 & 0.1332 & 0.8465 \\
\hline PB-Mg & 394.72 & 0.0170 & 0.9724 & 50.32 & 0.3175 & 0.9667 \\
\hline
\end{tabular}

Table 5. Maximum CR adsorption capacity by various biochars.

\begin{tabular}{|c|c|c|c|}
\hline Feedstock & Treatment & Max. adsorption capacity (mg/g) & References \\
\hline Orange peel waste & Microwave heating and activation by steam & 192.3 & [35] \\
\hline Litchi peel waste & Hydrothermal carbonization and subsequent activation & 404.4 & {$[26]$} \\
\hline Macroalgae & Pyrolysis at $800^{\circ} \mathrm{C}$ & 345.2 & [34] \\
\hline Switchgrass & Pyrolysis at $900^{\circ} \mathrm{C}$ & 22.6 & [36] \\
\hline Rice straw & Pyrolysis at $500^{\circ} \mathrm{C}$ & 190.8 & [19] \\
\hline Crab shell & Pyrolysis at $800^{\circ} \mathrm{C}$ & 20,317 & [32] \\
\hline
\end{tabular}


이용하여 바이오차의 $\mathrm{CR}$ 에 대한 흡착 성능을 크게 증가시 킬 수 있으며, 본 연구에서 제조한 $\mathrm{KB}-\mathrm{Mg}$ 및 $\mathrm{PB}-\mathrm{Mg}$ 이 $\mathrm{CR}$ 흡착 제거를 위한 높은 잠재력을 가지고 있음을 보여주는 것이다.

\section{4. 결 론}

다시마와 소나무를 $\mathrm{MgCl}_{2}$ 로 전처리하여 제조한 $\mathrm{Mg}$-바이 오차 복합재의 기본적인 물리·화학적 특성을 분석하고 음 이온 염료인 $\mathrm{CR}$ 에 대한 흡착성능을 평가하였다. $\mathrm{SEM}, \mathrm{EDS}$ 및 $\mathrm{XRD}$ 를 이용한 분석은 $\mathrm{KB}-\mathrm{Mg}$ 와 $\mathrm{PB}-\mathrm{Mg}$ 모두 표면개질 을 통해 $\mathrm{Mg}$ 화합물이 표면에 잘 분포되어 있으며 주로 $\mathrm{MgO}$ 결정체로 존재한다는 것을 보여 주었다. 일반 바이오차를 $\mathrm{MgCl}_{2}$ 로 표면개질을 하면 모든 $\mathrm{pH}$ 영역(5 - 10)에서 $\mathrm{CR}$ 에 대한 흡착 성능이 크게 향상되었다. 흡착 동력학적 분석은 모든 바이오차에서 $\mathrm{CR}$ 에 대한 흡착 반응이 유사 2차 반응 속도 모델을 가장 잘 따르며 경계층을 통과하는 $\mathrm{CR}$ 의 질량 이전이 흡착 반응속도를 결정하는 요소임을 보여주었다. 모 든 바이오차의 등온 흡착성능 특성은 Freundlich모델보다 Langmuir 모델이 더 적합하며 $\mathrm{KB}-\mathrm{Mg}$ 와 $\mathrm{PB}-\mathrm{Mg}$ 의 $\mathrm{CR}$ 에 대 한 Langmuir 최대 흡착성능은 각각 $423.0 \mathrm{mg} / \mathrm{g}, 394.7 \mathrm{mg} / \mathrm{g}$ 이었다. $\mathrm{Mg}$-바이오차의 $\mathrm{CR}$ 흡착에 대한 주요 기작은 $\mathrm{CR}$ 과 바이오차 간의 정전기 인력으로 판단된다. 본 연구에서 얻 은 결과는 $\mathrm{MgCl}_{2}$ 를 이용하여 바이오차의 $\mathrm{CR}$ 에 대한 흡착 성능을 크게 증가시킬 수 있음을 보여주었다.

\section{Acknowledgement}

본 결과물은 교육부와 한국연구재단의 재원으로 지원을 받아 수행된 사회맞춤형 산학협력 선도대학(LINC+) 육성사 업의 연구결과입니다.

\section{References}

1. H. Shin, D. Tiwari, D.-J. Kim, Phosphate adsorption/ desorption kinetics and $\mathrm{P}$ bioavailability of Mg-biochar from ground coffee waste, J. Water Process Eng., 37, 101484 (2020).

2. M. Hassan, Y. Liu, R. Naidu, S. J. Parikh, J. Du, F. Qi, I. R. Willett, Influences of feedstock sources and pyrolysis temperature on the properties of biochar and functionality as adsorbents: a meta-analysis, Sci. Total Environ., 744, 140714(2020)

3. H. K. S. Panahi, M. Dehhaghi, Y. S. Ok, A.-S. Nizami, B. Khoshnevisan, S. I. Mussatto, M. Aghbashlo, M. Tabatabaei, S. S. Lam, A comprehensive review of engineered biochar: Production, characteristics, and environmental applications, J. Clean. Prod., 270, 122462(2020).

4. X.-f. Tan, Y.-g. Liu, Y.-l. Gu, Y. Xu, G.-m. Zeng, X.-j. Hu,
S.-b. Liu, X. Wang, S.-m. Liu, J. Li, Biochar-based nano-composites for the decontamination of wastewater: a review, Bioresour. Technol., 212, 318-333(2016).

5. M. Zhang, B. Gao, Removal of arsenic, methylene blue, and phosphate by biochar/AlOOH nanocomposite, Chem. Eng. J., 226, 286-292(2013).

6. S.-b. Liu, X.-f. Tan, Y.-g. Liu, Y.-1. Gu, G.-m. Zeng, X.-j. Hu, H. Wang, L. Zhou, L.-h. Jiang, B.-b. Zhao, Production of biochars from $\mathrm{Ca}$ impregnated ramie biomass (Boehmeria nivea (L.) Gaud.) and their phosphate removal potential, RSC Adv., 6, 5871-5880(2016).

7. D.-W. Cho, G. Kwon, Y. S. Ok, E. E. Kwon, H. Song, Reduction of bromate by cobalt-impregnated biochar fabricated via pyrolysis of lignin using $\mathrm{CO}_{2}$ as a reaction medium, ACS Appl. Mater. Interfaces., 9, 13142-13150(2017).

8. R. He, Z. Peng, H. Lyu, H. Huang, Q. Nan, J. Tang, Synthesis and characterization of an iron-impregnated biochar for aqueous arsenic removal, Sci. Total Environ., 612, 1177-1186(2018).

9. C. Fang, T. Zhang, P. Li, R. Jiang, S. Wu, H. Nie, Y. Wang, Phosphorus recovery from biogas fermentation liquid by Ca-Mg loaded biochar, J. Environ. Sci., 29, 106-114(2015).

10. C. Gan, Y. Liu, X. Tan, S. Wang, G. Zeng, B. Zheng, T. Li, Z. Jiang, W. Liu, Effect of porous zinc-biochar nanocomposites on $\mathrm{Cr}(\mathrm{VI})$ adsorption from aqueous solution, RSC Adv., 5, 35107-35115(2015).

11. H. Xia, L. Chen, Y. Fang, Highly efficient removal of Congo red from wastewater by nano-CaO, Sep. Sci. Technol., 48(17), 2681-2687(2013).

12. J. Zolgharnein, S. D. Farahani, M. Bagtash, S. Amani, Application of a new metal-organic framework of $\left.\left[\mathrm{Ni}_{2} \mathrm{~F}_{2} \text { (4,4'-bipy }\right)_{2}\left(\mathrm{H}_{2} \mathrm{O}\right)_{2}\right]\left(\mathrm{VO}_{3}\right)_{2} \cdot 8 \mathrm{H}_{2} \mathrm{O}$ as an efficient adsorbent for removal of Congo red dye using experimental design optimization, Environ. Res., 182, 109054(2020).

13. H. S. Oh, J.-S. Chang, Comparison of cation anion dye removal characteristics between kelp-based magnetic biochar and pine-based magnetic biochar, J. Korean Soc. Environ. Eng., 42(6), 308-318(2020).

14. Y.-H. Jiang, A.-Y. Li, H. Deng, C.-H. Ye, Y.-Q. Wu, Y.-D. Linmu, H.-L. Hang, Characteristics of nitrogen and phosphorus adsorption by Mg-loaded biochar from different feedstocks, Bioresour. Technol., 276, 183-189(2019).

15. R. Li, J. J. Wang, B. Zhou, Z. Zhang, S. Liu, S. Lei, R. Xiao, Simultaneous capture removal of phosphate, ammonium and organic substances by $\mathrm{MgO}$ impregnated biochar and its potential use in swine wastewater treatment, J. Clean. Prod., 147, 96-107(2017).

16. S. V. Novais, M. D. O. Zenero, J. Tronto, R. F. Conz, C. E. P. Cerri, Poultry manure and sugarcane straw biochars modified with $\mathrm{MgCl}_{2}$ for phosphorus adsorption, J. Envriron. Manage., 214, 36-44(2018).

17. Z. Shen, J. Zhang, D. Hou, D. C. Tsang, Y. S. Ok, D. S. Alessi, Synthesis of MgO-coated corncob biochar and its application in lead stabilization in a soil washing residue, Environ. Int., 122, 357-362(2019). 
18. R. Lakshmipathy, N. C. Sarada, Watermelon rind for sequestration of contaminants: A superior adsorbent for the removal of heavy metal ions and synthetic dyes from aqueous solution, Lap Lambert Academic Publishing, pp. 31-32(2014).

19. D. D. Sewu, P. Boakye, S. H. Woo, Highly efficient adsorption of cationic dye by biochar produced with korean cabbage waste, Bioresour. Technol., 224, 206-213(2017).

20. N. A. Qambrani, M. M. Rahman, S. Won, S. Shim, C. Ra, Biochar properties and eco-friendly applications for climate change mitigation, waste management, and wastewater treatment: A review, Renew. Sust. Energ. Rev., 79, 255-273 (2017).

21. E.-B. Son, K.-M. Poo, J.-S. Chang, K.-J. Chae, Heavy metal removal from aqueous solutions using engineered magnetic biochars derived from waste marine macro-algal biomass, Sci. Total Environ., 61515, 161-168(2018).

22. H.-L. Seo, T.-Y. Yin, O.-I. Kwon, K. Chon, Effects of oxidative and alkaline post-treatments on removal of trivalent iron and hexavalent chromium using peanut shell biochars, J. Korean Soc. Environ. Eng., 42(2), 55-65(2020).

23. G.-Y. Kim, Y. H. Seo, I. Kim, J.-I. Han, Co-production of biodiesel and alginate from Laminaria japonica, Sci. Total Environ., 673, 750-755(2019).

24. I. D. Mall, V. C. Srivastava, N. K. Agarwal, I. M. Mishra, Removal of congo red from aqueous solution by bagasse fly ash and activated carbon: Kinetic study and equilibrium isotherm analyses, Chemosphere, 61(4), 492-501(2005).

25. J. Kwak, S. Park. J. Shin, K. Chon, Effects of the pyrolysis temperature on adsorption of carbamazepine and ibuprofen by $\mathrm{NaOH}$ pre-treated pine sawdust biochars, J. Korean Soc. Environ. Eng., 42(2), 29-39(2020).

26. J. Wu, J. Yang, P. Feng, G. Huang, C. Xu, B. Lin, High-efficiency removal of dyes from wastewater by fully recycling litchi peel biochar, Chemosphere, 246, 125734 (2020).

27. R. Hasan, C. C. Chong, S. N. Bukhari, R. Jusoh, H. D. Setiabudi, Effective removal of $\mathrm{Pb}$ (II) by low-cost fibrous silica KCC-1 synthesized from silica-rich rice husk ash, J. Ind. Eng. Chem., 75, 262-270(2019).

28. F. Güzel, H. Sayğılı, G. A. Sayğılı, F. Koyuncu, Decolorisation of aqueous crystal violet solution by a new nanoporous carbon: Equilibrium and kinetic approach, J. Ind. Eng. Chem., 20, 3375-3386(2014).

29. S. Parvin, B. K. Biswas, A. Rahman, H. Rahman, S. Anik, R. Uddin, Study on adsorption of Congo red onto chemically modified egg shell membrane, Chemosphere, 236, 124326(2019).

30. H. Li, J. Hu, Y. Meng, J. Su, X. Wang, An investigation into the rapid removal of tetracycline using multilayered graphene-phase biochar derived from waste chicken feather, Sci. Total Environ., 603, 39-48(2017).

31. F. Reguyal, A. K. Sarmah, Site energy distribution analysis and influence of $\mathrm{Fe}_{3} \mathrm{O}_{4}$ nanoparticles on sulfamethoxazole sorption in aqueous solution by magnetic pine sawdust biochar, Environ. Pollut., 233, 510-519(2018).

32. L. Dai, W. Zhu, L. He, F. Tan, N. Zhu, Q. Zhou, M. He, $\mathrm{G}$. Hu, Calcium-rich biochar from crab shell: An unexpected super adsorbent for dye removal, Bioresour. Technol., 267, 510-516(2018).

33. P. Nautiyal, K. A. Subramanian, M. G. Dastida, Adsorptive removal of dye using biochar derived from residual algae after in-situ transesterification: Alternate use of waste of biodiesel industry, J. Environ. Manage., 182, 187-197(2016).

34. Y.-d. Chen, Y.-C. Lin, S.-H. Ho, Y. Zhou, N.-q. Ren, Highly efficient adsorption of dyes by biochar derived from pigments-extracted macroalgae pyrolyzed at different temperature, Bioresour. Technol., 259, 104-110(2018).

35. P. N. Y. Yek, W. Peng, C. C. Wong, R. K. Liew, Y. L. Ho, W. A. W. Mahari, E. Azwar, T. Q. Yuan, M. Tabatabaei, M. Aghbashlo, C. Sonne, S. S. Lam, Engineered biochar via microwave $\mathrm{CO}_{2}$ and steam pyrolysis to treat carcinogenic Congo red dye, J. Hazard. Mater., 395, 122636(2020).

36. J.-H. Park, J. J. Wang, Y. Meng, Z. Wei, R. D. DeLaune, D.-C. Seo, Adsorption/desorption behavior of cationic and anionic dyes by biochars prepared at normal and high pyrolysis temperatures, Colloids Surf., A, 572, 274-282(2019).

\section{Authors}

\section{Hee So Oh}

Department of Environmental Engineering, Korea Maritime and Ocean University, Master Graduate, ORCID (1) 0000-0001-87826187

\section{Jae-Soo Chang}

Department of Environmental Engineering, Korea Maritime and Ocean University, Associate Professor, ORCiD (D) 0000-0001-92589921 